Article

\title{
The Economic and Ethical Implications of Living Wages
}

\author{
Joyce Ann Konigsburg \\ Duquesne University, 600 Forbes Ave, Pittsburgh, PA 15282, USA; konigsburgj@duq.edu \\ Academic Editors: Kate Ward and Kenneth Himes \\ Received: 9 March 2017; Accepted: 14 April 2017; Published: 20 April 2017
}

\begin{abstract}
Although rhetoric about wages and jobs often emphasizes the effects of globalization, questions remain as to whether United States workers are paid adequately to sustain a reasonable standard of living. One solution is to implement a living wage, which is accurate and specific to a local economy but more computationally complex than a one-size-fits-all minimum wage. When considered economically, a living wage has the potential to increase business and production costs as well as lower profits and cause job loss. From ethical viewpoints articulated in Catholic social thought, sustainable wages enhance human dignity by supporting human agency, encouraging creativity, and permitting contributions to the common good. This article explores whether the positive ethical outcomes of implementing a living wage outweigh any possibly negative, unintended economic results.
\end{abstract}

Keywords: economic inequality; social justice; interdisciplinary studies; living wages; just wages; economic implications; ethical implications

\section{Introduction}

Although it debuted in the late 1970's, Italian playwright Dario Fo's working-class farce, translated as “They Don't Pay? We Can't Pay!" or more emphatically “We Won't Pay! We Won't Pay!" captures the timeless struggle between employer profits and employee wages. In the story, an economic downturn forces a factory to reduce workers' wages while at the same time rent is due and prices at the local market soar. Frustrated and desperate, women shoppers loot the store, stealing food for their tables. They hide the items under coats, appearing to be pregnant in order to fool their husbands and the police. Slapstick adventures ensue. Yet the play raises serious ethical issues regarding human rights, dignity, and survival in unjust economic conditions. Of fundamental concern is whether workers in the United States are paid adequately to support a reasonable standard of living and accumulate long-term wealth. From ethical viewpoints articulated in Catholic social thought, sustainable wages enhance human dignity by supporting human agency, encouraging creativity, and permitting contributions to the common good. They also enable greater economic, community, and political participation, thereby promoting justice. One solution to inadequate compensation is the notion of a living wage, which frequently differs from legislated national minimum wage amounts. Because a living wage reflects specific local economic conditions, it more accurately meets a worker's basic needs in a particular area. The ultimate question regarding living wage proposals is whether the positive ethical effects of reducing wage inadequacy and its resultant poverty are economically sustainable.

\section{Living Wage Definition}

Local living wage ordinances comprise multiple types of benefits that affect various categories of employees. By definition, a living wage enables a person to support oneself and one's family without government assistance. As a result, workers contribute to society by paying taxes, by acquiring wealth for long-term goals, and by spending their income locally, which stimulates economic development, 
often in the neediest communities. (See Stephen Leccese's work in this volume on historical views of workers' wages and spending in the economy.) Unlike a one-size-fits-all minimum wage floor, living wages are tailored to the local economy and its standard of living, which makes the wage more accurate but involves a more complex calculation and definition. A living wage calculator estimates an hourly wage for a 40-hour workweek that affords one head-of-household (with various combinations that comprise a family) the means to live in a certain area. The Austin-Round Rock, Texas area, for example, calculates an income based on costs of shelter, taxes, and utilities at fair market housing rates [1]. Additionally, the wage includes per person food allowances from the USDA's Thrifty Food Plan tables, average medical insurance prices across age groups, budgets for clothing, personal items, and transportation from consumer expenditure surveys, along with a small budget allocation for long-term expenses and savings.

\section{Economic Implications of a Living Wage}

One advantage to local living wage ordinances is their flexibility and customization to a specific community's economic conditions. Businessmen such as Henry Ford and Edward Filene understood that paying reasonable wages was sound business policy; the practice expands a laborer's purchasing power and enables him or her to buy the company's products ([2], p. 5). A rise in aggregate demand stimulates the economy, especially since "low-wage workers are more apt to spend earnings locally, circulating money back into local economies" ([2], p. 6). Thus, "increasing the economic self-sufficiency of workers enhances business productivity and opens new markets, while also reducing poverty, strengthening communities, and shrinking the demand for government assistance to low-income families" ([2], p. 7). These positive multiplier effects help rebuild lives and strengthen local economies.

Increasing worker pay above the poverty line to a living wage not only helps families escape the stigma of poverty, it also reduces reliance on government welfare programs. Many workers and their families receive public assistance because their employers do not pay enough to meet the employee's basic needs ([3], p. 5). Rather than encourage businesses to compensate employees appropriately, the government, through taxpayers, subsidizes businesses that pay low wages. The government also loses revenue from income and social security taxes when businesses pay minimal wages, rather than higher living wages in some areas [4]. A living wage must be sufficient to support a person without government subsidies; otherwise, it "could increase cash earnings only at the expense of other forms of income, changing the composition but not the amount of income" [5]. As incomes increase, workers reduce their reliance on government assistance. Living wage earners are able to pay their taxes, contribute to social security, and save for emergencies as well as their own retirement. In doing so, some of the living wages costs affecting business owners and consumers are offset by gains to small businesses and individual taxpayers at federal and local levels.

Not only do workers and taxpayers benefit from living wages, business owners profit in a variety of ways. The efficiency wage hypothesis suggests, "the productivity of a firm's employees increases as their wage is increased, at least over an economically relevant part of its [wage] range" ([6], p. 848). With less absenteeism, and lower turnover, the estimated cost savings for companies "could be as high as 20 to 25 percent of their total living wage costs" ([7], p. 19). For instance, the owner of travel agency, Idyll, Ltd., concedes "the trade-off for paying decent wages is lower immediate profits, but adds that his costs would be up in other areas (recruitment and training) if he 'skimped on employee pay'"' ([2], p. 17). In Los Angeles for example, security screeners had a high turnover rate of 94.7 percent before the living wage, but their turnover rate dropped to just 18.7 percent when earnings increased from $\$ 6.45$ to $\$ 10.00$ an hour ([8], pp. 10,54). Reduced employee attrition lowers recruiting and training costs while cultivating an experienced workforce. Furthermore, satisfied clients generate repeat business with less marketing and sales effort, which yields higher profit margins and added benefits ([8], pp. 9-10). Because living wage ordinances prevent government contract bidders from undercutting wages or benefits, service quality becomes a key differentiator among competitors ([9], pp. 21-23). To summarize, 
employee loyalty as well as proficiency results in higher product quality, efficiency, and consistent customer service, all of which are in the self-interest of company managers and owners.

Most economic models predict that higher wages result in greater production costs. Rising production costs increase prices for goods, which reduce product demand until the supply and demand curves reach a new equilibrium point. Demand elasticity however may not be as strong an economic influence since "a living wage stimulates the overall demand for goods and services in the economy and can result in job growth" [4]. Likewise, standard economic efficiency theories argue that increasing wages drives less efficient employers out of business or causes layoffs. In these situations, "employers may find ways to offset the increased labor costs for low-wage labor by reducing costs in other dimensions" ([10], p. 32) such as improving processes, utilizing technology, or using labor more effectively. As a result, employers expect greater productivity from workers, so, it is logical for "some [job] substitutions to occur, both by educational credentials and age, though, the magnitude of such substitutions is likely to be modest" ([7], p. 33). Most labor layoff/substitution occurs at living wage ordinance boundaries, either by area or by business-type, because better skilled people earning between minimum and living wage apply and are hired for comparable living wage jobs. Although job substitution does not alter the goal of paying workers livable wages, it does affect who earns the higher wage.

Neoclassical economic theory also predicts greater unemployment when wages increase. Living wages potentially cause unintended effects, especially "if employers need to raise the wages of other workers to maintain a wage hierarchy within the firm, [then] the ripple effect can cause even greater employment losses" ([11], p. 14). However, it is difficult to determine the extent of these losses. An Economic Policy Institute study in 1998 concluded that "after four years in force, the Baltimore living wage increase did not result in any discernible job loss" ([2], p. 10). In fact, research by Card and Krueger corroborate studies by Neumark and Wascher that living wage or "higher minimum wage mandates do not behave in the manner predicted by competitive models and that average firm employment does not decline but may in fact increase slightly following minimum wage increases" ([9], p. 6). The unemployed often fill positions that the formerly underemployed no longer need to make ends meet. When asked what a worker was going to do with the extra money after Alexandria, VA passed its living wage ordinance, he replied, "Quit my third job!" ([12], p. 26). Evidence reveals that employment rates hold relatively steady if the coverage area or wage increases are modest.

Implementing living wages may prompt businesses to relocate operations to more favorable, cost-effective locations. Economically, "firms should be drawn to low-wage areas, causing job growth to be highest where pay is lowest, as long as all other things-taxes, public services, rents, access to customers and so forth-are equal" ([13], p. 6). However, several factors go into a decision to relocate. The issues include labor and production costs, customer base, business type, labor supply, and the area economy. Sometimes a location has intrinsic value, such as waterfront, views, or proximity to sports arenas or convention centers, which complicates the decision. Existing companies ultimately must decide whether the marginal benefits of relocation are greater than the costs of relocation in addition to living wage cost increases.

Whether a business relocates, absorbs expenses, or raises prices depends on factors such as the cost increase percentage, the firm's competition, and the product's demand elasticity. If production costs increase one to two percent, companies may decide to absorb expenses rather than risk losing business ([9], p. 24). Likewise, some effects of raising prices are minimal. At the San Francisco airport, for example, passing higher employee compensation costs to consumers results in an increase of $\$ 1.42$ per passenger ([8], pp. 9, 49). With living wage ordinances, it is easier for local firms competing for similar business to raise their prices since their competitors face similar cost increases. Yet increasing prices in global markets is problematic because competitors are not subject to local living wage rules. 


\section{Ethical Implications of a Living Wage}

The economic implications of a living wage address whether wages can be increased but not whether wages should be increased. Evaluating the ethical implications of a living wage involves what it does for and to the people and how people subsequently participate in the economy ([14], para. 1, 13). Hence, according to Catholic social teaching a living wage is ethical if it upholds human rights and dignity, supports the common good, enables participation, creates right relationships, and secures economic justice for all stakeholders.

The Christian principle of human dignity states that each human being is sacred and holy because a person is a child of God; made in God's image. Dignity comes from God, not from one's livelihood, salary, or bank account totals. Although humans possess the talents and skills necessary to build wealth through labor, merely possessing wealth hinders one's ultimate goal of eternal life; instead, wealth must be used justly ([15], para. 22, 34-35). God therefore calls humanity to co-create, to transform the earth through work, which is good and thus enhances human dignity ([16], para. 9, 25). Work entails more than a fair income; it encourages people to grow and develop by sharing in the responsibility and creativity of the labor process. A worker offers labor in return for sustenance and a share in God's creation, so a laborer has a natural right to a wage that sustains a person and his or her children, one that adequately addresses one's essential needs ([15], para. 9, 32, 61-63). In the Catholic tradition, economic institutions are to serve workers rather than exploit them ([14], para. 13, 28). Employers promote human dignity by respecting workers, considering their well-being, protecting religious freedom and property, besides paying them what they are justly due ([15], para. 31-32). With just (living) wages for just work, employers as well as employees contribute to the common good.

Humans are by nature social beings; they find their identity and full development by participating in community. Work is one form of interrelated participation with others. Consequently, the employee, employer, and consumer all have duties within the economic order. The employee's duty is to contribute value to a company's product in return for a wage as well as "contributing to the common good, according to his [sic] own abilities and the needs of others" ([17], para. 30). Economist Milton Friedman asserts the social responsibility of business is "to use its resources and engage in activities designed to increase its profits" ([18], p. 1). However, Catholic social teaching views business as a particular group of people striving to satisfy their basic needs in service to society in general ([19], para. 35). An employer's duty is to provide just wages to all workers since "to exercise pressure for the sake of gain, upon the indigent and destitute, and to make one's profit out of the need of another, is condemned by all laws, human and divine" ([15], para. 17). Early in the twentieth century, employers believed they had a moral responsibility to pay their workers a living wage and those "who paid less than a living were viewed as harming not only their workers' health and morals but the health of the community as well" ([20], pp. 216-17). Without living wages, people must meet their basic needs by working longer hours, sometimes at multiple workplaces, which leaves little time for family, faith, or civic activities.

Consumer decisions also directly influence wages; yet few shoppers consider their roles in supporting living wages. Too frequently, "people want cheaper shoes and most do not care who makes them" ([21], p. 417). Many people claim invincible ignorance since they seldom ponder what businesses must do to offer low prices and still make a profit. Commerce, along a global supply chain, entails an interrelated dependence among persons, states, and various socio-economic institutions, all of which Pope John Paul II refers to as indirect employers ([16], para. 17). Consequently, high wages and low prices often conflict because paying living wages along the entire supply chain quickly gets complicated and expensive [22]. But John Ryan argues that the consumer "is morally bound to pay such prices for goods as will enable all business men [sic] to obtain a decent livelihood" ([23], p. 362). By purchasing items from ethical firms paying adequate wages, consumers take moral responsibility for their buying behaviors; their product choices reflect their cultural values ([19], para. 36). Furthermore, consumers should choose ethical investments so that present and future capital eventually benefits individuals along with the common good. 
Critical ethical indicators of society's economic health include its wealth production as well as its income distribution. (See Kenneth Himes' work in this volume on John Ryan regarding wage ceilings and floors.) In 1965, the average American CEO-to-worker pay ratio was 20-to-1; but 50 years later, the ratio was 303-to-1 ([24], pp. 2, 6). The principle of solidarity suggests, "when ratios of compensation between highest and lowest paid workers in a firm become too great; there is a loss of unity and reciprocity" ([25], p. 14). If a society values individualism rather than solidarity, then it creates a Darwinian survival-of-the-fittest attitude rather than a community of persons working toward the common good. Consequently, the result is income inequality. Excessive inequality hinders a community's ability to solve problems or achieve common objectives; societies grow more slowly and have more trouble adjusting to changes than those with equitable distributions of wealth and income ([26], p. 15). (See Kate Ward's work in this volume on inequality and the virtue of hospitality.) One's inability to keep pace with rising costs while observing others' incomes increase rapidly, causes discord, strife, violence for society and violates a value of fairness and societal cooperation [27]. Reassuringly, wealth distribution is a social scheme, so it is open to improvement. Catholic social teaching supports just distribution of income through the stewardship of low-interest loans, such as micro-loans, which allow low-income people to start small business, buy homes, and better themselves through hard work ([14], para. 265, 274-79). Moreover, profit sharing, stock ownership, and pension/retirement programs also effectively distribute business capital to workers ([14], para. 300). Trade and labor unions likewise contribute to equable income distribution when they collectively negotiate of behalf of workers without harming vulnerable members of society or the common good ([14], para. 106). Equitable income distribution promotes workplace harmony in addition to a just economy.

Another vital component to sustaining community is the inclusion and participation of all citizens in its economy. Because the current economic system requires wealth in order to participate, from a Catholic social thought perspective, it would be judged an unjust failure. The inability to participate in political or economic activity is the ultimate injustice toward a person and rectifying it is the highest social priority ([14], para. 77,91). Rectifying this injustice requires a preferential option for the poor, which calls for greater solidarity with and among the underprivileged in economic and political decisions, especially regarding employment and wages ([14], para. 88). By promoting the common good, "human dignity of all is realized when people gain the power to work together to improve their lives, strengthen their families, and contribute to society" ([14], para. 91) since basic justice calls for economic participation through employment and property ownership. Nevertheless, to participate fully in the economy and obtain property, people require an adequate flow of income that enables long-term accumulated wealth. Eventually, amassed wealth provides insurance for emergencies plus collateral for business loans, mortgages, or capital purchases. A living wage therefore establishes economic justice ([28], p. 69). In addition to a living wage, workers require adequate health care, job and old age security, healthy working conditions, and periodic rest for rejuvenation ([14], para. 103). Solidarity interconnects all people worldwide; nevertheless, global markets create intense competition for inexpensive labor. However, respect for worker's rights and dignity must direct appropriate living wage solutions for each nation's and the world's economies ([16], para. 17). Behaving ethically and responsibly dissuades unfair business competition that takes advantage of impoverished workers who must compete against each other for low-paying jobs.

Wealth accumulation creates private property for workers. According to Catholic social teaching, the right to private property is sacred and represents wages in a different form ([15], para. 4, 35). Ownership, however, equates to stewardship of goods originally meant for all, thus, private property has a social dimension; the state has the duty to prevent people from abusing private property rights and harming the common good ([14] para. 114-15). As a result, philosophical debates ensue over whether government has the authority to regulate the price of labor. One side of the argument appeals to workers' rights, dignity, and justice, while the other side claims regulations are a form of coercion, which violates their property rights ([29], pp. 156-60). The first argument appeals to notions of social and economic 
justice, which utilize moral principles to create economic institutions that distribute wealth, property, and opportunities within society that benefits the whole society. In terms of commutative justice, which involves justice between two individuals or entities, those arguing against wage regulation perceive it to be unfair to businesses. Instead, they favor market forces for setting wages; yet, what is referred to as the free market is not free at all because government agencies often manipulate interest rates and other economic indicators while granting businesses billions of dollars in subsidies, tax breaks, and other forms of corporate welfare in the name of economic growth ([3], pp. 12-15). Both viewpoints concede that wages enabling people to live above the poverty line are a noble goal, as long as it respects the rights of both employer and employee through free negotiation. Nevertheless, a delicate balance exists between economic justice and fiscal prudence that influences government action. If the government establishes living wage regulations without creating economic and social structures to support it, then many individual employers cannot unilaterally pay wages above the market wage; they will be unable to compete. Competitors utilizing inexpensive overseas labor or other cost cutting supply-chain mechanisms force other firms to cut wages, lay off workers, relocate abroad, or close.

The broad role of government is to promote security, encourage prosperity, and provide protection for all citizens. For example, the United States government has a history of setting job quality standards, which include minimum wage laws, overtime requirements, prohibitions against child labor, occupational safety and health standards, family and medical leave, and now living wage ordinances. However, the State is not expected to resolve every social problem. In Catholic social teaching, the principle of subsidiarity claims that the most local levels of governance are more appropriate for determining responsibilities and making decisions within communities since the individual, the family, and society are all prior to the State ([14], para. 99). According to this principle, the business community is the proper level of subsidiary to establish living wage amounts and regulations. If companies ignore their duty or are unable to sustain their business at just wage rates, then the State has a duty to protect its citizens, especially the vulnerable ones. Government regulation frequently causes tension between conflicting viewpoints regarding commutative and social justice. What appears to be coercion or a violation of property rights to businesses may in fact be State intervention to benefit society. By legislating living wages, the State imposes the stewardship function on businesses to share their wealth in a just manner that benefits the common good.

Two primary components of economic justice entail the right to work and the right to a just wage. For a living wage to be considered just, it must sustain worker and family expenses with enough income to acquire long-term wealth. A fair wage also includes a benefits package and skills training. In a just worker-employer relationship, "an employer must recognize that employees 'surrender' their time and energy and so they cannot use it for another purpose" ([30], pp. 10-11), thereby requiring a living wage in return. Furthermore, the free consent of both parties is necessary. If workers agree to low wages under duress, then the arrangement is unjust and invalid ([15], para. 61, 63). For businesses, profits are an essential, legitimate goal, but not at the expense of paying unjust wages. As President Franklin D. Roosevelt said, "No business that depends for existence on paying less than living wages has any right to continue in this country" ([31], p. 14). Worker rights take precedence, so laborers should be paid a living wage prior to determining business profits. On the one hand, "it would be unjust to demand excessive wages, which a business cannot pay without its ruin and consequent calamity to the workers" ([32], para. 72). On the other hand, businesses are not to use this principle of feasibility to act inefficiently or to supplement low wage rates with government programs.

\section{Conclusions}

In Catholic social thought, businesses have the moral responsibility to act as stewards of a company's property and profits and to establish right relationships with their employees by paying them just wages. The economic benefits from paying living wages are increased productivity, quality, innovation, and morale, all of which contribute to greater profits. Failing to do so, the government has an obligation to protect society, especially the poorest workers, and to ensure the common good for all. 
Ethical consumer choices also maintain solidarity and a healthy economic order for all stakeholders. However, a living wage involves more than increasing a person's hourly rate of pay. In adding value to finished products, a worker establishes the right to a living wage. The act of escaping poverty then sustaining a livelihood without government subsidies restores human dignity and builds wealth. With security and wealth, workers participate in family, economic, and political activities, thereby contributing to the common good. Consequently, the notion of living wages is sustainable economically and supportable ethically.

Conflicts of Interest: The author declares no conflict of interest.

\section{References}

1. Amy K. Glasmeier. “Living Wage Calculation for Austin-Round Rock, TX." Massachusetts Institute of Technology Living Wage Calculator. Available online: http:/ /livingwage.mit.edu/metros/12420 (accessed on 15 February 2017).

2. Karen Kraut, Scott Klinger, and Chuck Collins. Choosing the High Road: Businesses that Pay a Living Wage and Prosper. Boston: Responsible Wealth, 2000.

3. Carol Zabin, Arindrajit Dube, and Ken Jacobs. The Hidden Public Costs of Low-Wage Jobs in California. Berkley: The National Economic Development and Law Center, University of California, Berkley, 2004.

4. Ralph Scharnau. "American Workers Deserve Enactment of U.S. Living Wage; Congressional Pay Goes up, But the Federal Minimum Has Not Risen Since 1997." Dubuque Telegraph Herald, 7 August 2005.

5. Craig Garthwaite. "Living Wage' Laws Don't Help Low-Income Families.” Budget \& Tax News, 1 September 2005.

6. James M. Malcomson. “Unemployment and the Efficiency Wage Hypothesis." The Economic Journal 91 (1981): 848-66. [CrossRef]

7. Robert Pollin. "Evaluating Living Wage Laws in the United States: Good Intentions and Economic Reality in Conflict? " Journal of Strategic Contracting and Negotiation 19 (2005): 3-24. [CrossRef]

8. Michael Reich, Peter Hall, and Ken Jacobs. Living Wages and Economic Performance: The San Francisco Airport Model. Berkeley: Institute of Industrial Relations, 2003.

9. Mark Brenner. The Economic Impact of Living Wage Ordinances. Amherst: Political Economy Research Institute, 2003.

10. David Neumark. "Living Wages: Protection for or Protection from Low-Wage Workers? "Industrial and Labor Relations Review 58 (2004): 27-51. [CrossRef]

11. Madeline Zavodny. "Reexamining the Minimum Wage." In Southwest Economy. Dallas: Federal Reserve Bank of Dallas, 1996, pp. 12-15.

12. Bobbi Murray. "Living Wage Comes of Age." The Nation 273 (2001): 24-27.

13. Lori L. Taylor. "The Border: Is It Really a Low Wage Area? " In Monograph. Dallas: Federal Reserve Bank of Dallas, 2001, pp. 6-8.

14. National Conference of Catholic Bishops. "Economic Justice for All: On Catholic Social Teaching and the U.S. Economy." In Catholic Social Teaching: The Documentary Heritage. Edited by David J. O'Brien and Thomas Shannon. Maryknoll: Orbis Books, 1992, pp. 572-680.

15. Leo, XIII. "Rerum Novarum (The Condition of Labor)." In Catholic Social Teaching: The Documentary Heritage. Edited by David J. O’Brien and Thomas Shannon. Maryknoll: Orbis Books, 1992, pp. 12-39.

16. John Paul, II. “Laborem Exercens (On Human Work)." In Catholic Social Teaching: The Documentary Heritage. Edited by David J. O'Brien and Thomas Shannon. Maryknoll: Orbis Books, 1992, pp. 350-92.

17. Paul, VI. "Gaudium et Spes (Pastoral Constitution on the Church in the Modern World)." In Catholic Social Teaching: The Documentary Heritage. Edited by David J. O'Brien and Thomas Shannon. Maryknoll: Orbis Books, 1992, pp. 164-237.

18. Anonymous. "Doing Well by Doing Good." The Economist 355 (2000): 65-67.

19. John Paul, II. "Centesimus Annus (On the Hundredth Anniversary of Rerum Novarum)." In Catholic Social Teaching: The Documentary Heritage. Edited by David J. O'Brien and Thomas Shannon. Maryknoll: Orbis Books, 1992, pp. 437-88.

20. Deborah M. Figart, Ellen Mutari, and Marilyn Power. Living Wages, Equal Wages: Gender and Labor Market Policies in the United States. New York: Routledge, 2002. 
21. Andrei Shleifer. “Does Competition Destroy Ethical Behavior? ” AEA Papers and Proceedings 94 (2004): 414-18. [CrossRef]

22. Andrew Muras. "Duties of the Consumer." Religion and Liberty 13 (2003): 10-12.

23. John A. Ryan. Distributive Justice: The Right and Wrong of Our Present Distribution of Wealth. New York: Macmillan, 1916.

24. Lawrence Mishel, and Alyssa Davis. “Top CEOs Make 300 Times More than Typical Workers: Pay Growth Surpasses Stock Gains and Wage Growth of Top 0.1 Percent." Economic Policy Institute Issue Brief, 21 June 2015, \#399.

25. Patricia Ann Lamoureux. "Is a Living Wage a Just Wage? " America, the National Catholic Weekly 184 (2001): 12-15.

26. Austin Equity Commission. Improving the Odds, Building a Comprehensive Opportunity Structure for Austin. Austin: Austin Equity Commission, 2001.

27. Bob Brownstein. "Is It Ethical to Shop at Wal-Mart? " Paper presented at the Ethics at Noon Conference, Santa Clara University Markkula Center for Applied Ethics, Santa Clara, CA, USA, 12 April 2004.

28. Lawrence B. Glickman. A Living Wage: American Workers and the Making of Consumer Society. Ithaca: Cornell University Press, 1997.

29. Helen Alford, and Michael J. Naughton. Managing as if Faith Mattered: Christian Social Principles in the Modern Organization. Notre Dame: University of Notre Dame Press, 2001.

30. Michael J. Naughton. “A Theology of Fair Pay." Regent Business Review 15 (2005): 9-14.

31. Richard Freeman. "Fighting for Other Folk's Wages: The Logic and Illogic of Living Wage Campaigns." Industrial Relations 44 (2005): 14-31.

32. Pius, XI. “Quadragesimo Anno (After Forty Years).” In Catholic Social Teaching: The Documentary Heritage. Edited by David J. O’Brien and Thomas Shannon. Maryknoll: Orbis Books, 1992, pp. 40-80.

(C) 2017 by the author. Licensee MDPI, Basel, Switzerland. This article is an open access article distributed under the terms and conditions of the Creative Commons Attribution (CC BY) license (http:/ / creativecommons.org/licenses/by/4.0/). 